\title{
A New Solidification Technology Of Municipal Solid Waste Incineration Fly Ash And Its Application In Asphalt Mixture
}

\author{
Lu Liang-zhi, ${ }^{1,2, a}$ Sun Jia-ying ${ }^{2, b}$ Yang Yi-fan ${ }^{1,2, c}$ Jiang Ying-bo ${ }^{2}$ \\ ${ }^{1}$ Department of Civil Engineering, Shanghai University, Shanghai 200072, China; \\ ${ }^{2}$ School of Civil Engineering and Architecture, Ningbo Institute of Technology, Zhejiang University, \\ Ningbo 315100, China. \\ aluliangzhi@live.cn.com, bjakys@163.com, yf920806@qq.com
}

Keywords: Fly Ash, Consolidation, Heavy Metals, Asphalt Mixture.

\begin{abstract}
Fly ash is consolidated by cement and the new consolidation agent, and the two kinds of cube samples $(40 \times 40 \times 40 \mathrm{~mm})$ used to consolidate the fly ash are made though the methods mentioned above; Comparing the strength of the samples for test resistance strength and flexural strength test after standard curing. The consolidation effect of the new curing agent for the metal ions in fly ash is better than that of cement, through the test of the heavy metal consolidation rate with different consolidation agent. By comparison with experimental data, it is concluded that the best substitution amount of fly ash is $75 \%$ in asphalt mixture. As well as testing physical and mechanical performance of specimens added optimum amount of fly ash, shows that the physical and mechanical properties of asphalt mixture with the new consolidation technology is better than that of ordinary asphalt mixture, and fly ash can be used as a filler in production of asphalt mixture.
\end{abstract}

\section{Introduction}

Incineration is one of the main methods to solve the municipal solid waste(MSW). The combustion products of municipal solid waste incineration(MSWI) include bottom ash and fly ash. In those papers[1,2], it shows heavy metals $(\mathrm{Pb}, \mathrm{Cr}, \mathrm{CD}, \mathrm{Cu}, \mathrm{Zn}, \mathrm{Hg})$ leaching out much easier riche in fly ash, it also contains dioxins and other toxic organic matter; If not timely and effective treatment, it will have a great influence on the surrounding environment, cause water, soil pollution and seriously harm to human health.

At present, there are three approaches for development and application in the incineration fly ash harmless and stable treatment all around the world[3]:1, secure landfill methods. 2, solidification-steady methods. 3, wet chemical treatment method. Owing to high cost of landfill method[4], the heavy burden to the waste incineration plant, as well as increasing the waste incineration also makes landfill site to hold more fly ash harder. It is waste of resources for secure landfill. The use of the consolidation treatment can not only reduce the harm of fly ash to the environment, but also make the most of resources. Liu Fu-yao[5]from Southwest Jiao Tong University have studied on the effect of fly ash and asphalt mixture ratio on the leaching of heavy metals in the asphalt though using the asphalt mixture on the medical waste incineration fly ash; The results show that it is much more appropriate to solidified with heavy metals like $\mathrm{Zn}, \mathrm{Pb}$ and $\mathrm{Cd}$. Peng Wen[6]from Zhejiang University, achieving the conclusion with the asphalt curing fly ash is that the leaching amount of heavy metals $(\mathrm{Cd}, \mathrm{Cu}, \mathrm{Ni}, \mathrm{Zn})$ is reduced, while the amount of asphalt increases, and it has a positive impact on the curing effect of fly ash. While the amount of $\mathrm{Pb}$ and $\mathrm{Cr}$ increases at first and then decreases, so the method has some limitations in the process of adding amount of asphalt, and it can be concluded that the fly ash can be used as the fine aggregate of asphalt mixture. This experiment will study further on the new solidification technology of municipal solid waste incineration fly ash and its application in asphalt mixture 


\section{Experiment}

\subsection{Raw Materials}

Cement produced by Zhejiang Sanshi Special Cement Co. Ltd. is P.O42.5, chemical composition and performance parameters are shown in Table 1. Sand used in this experiment is a natural river sand, fineness modulus is 2.58 in sand, bulk density is $1.54 \mathrm{~g} / \mathrm{cm} 3$, mud content is $0.94 \%$. Accord with China "Sand for construction"(GB/T 14684-2011). Coarse aggregat is limestone, adding limestone powder regulate grading with median for AC 16I in Table 2. Table 3 is aggregate technical index.

Table 1 The Composition of The Cement

\begin{tabular}{llllll}
\hline $\mathrm{SiO}_{2}$ & $\mathrm{Al}_{2} \mathrm{O}_{3}$ & $\mathrm{Fe}_{2} \mathrm{O}_{3}$ & $\mathrm{CaO}$ & $\mathrm{SO}_{3}$ & $\mathrm{MgO}$ \\
\hline 20.58 & 5.86 & 4.85 & 59.53 & 2.01 & 3.75 \\
\hline
\end{tabular}

The fly ash fitness is tested by water sieve method confirmed the " The Test Sieving Method for Fineness of Cement " (GB/T 1345-2005). Heavy metal content in fly ash is detected by ordinary acid decomposition method (i.e. four acid digestion method) with "The Technical Specification for soil Environmental monitoring" HJ/T 166- 2004, the method can measure the mass of every single heavy metal , and then convert into mass percentage. Fly ash fineness and fly ash heavy metals.

Table 2 AC-16 Grading Value

\begin{tabular}{|c|c|c|c|c|c|c|c|c|c|c|}
\hline $\begin{array}{r}\text { SieveType } \\
(\mathrm{mm}) \\
\text { Pass Rate\% }\end{array}$ & 0.075 & 0.15 & 0.3 & 0.6 & 1.18 & 2.36 & 4.75 & 9.5 & 13.2 & 16.0 \\
\hline $\begin{array}{l}\text { UpperGrading } \\
\text { Limit }\end{array}$ & 8 & 15 & 21 & 28 & 37 & 50 & 63 & 78 & 90 & 100 \\
\hline $\begin{array}{c}\text { Lower Grading } \\
\text { Limit }\end{array}$ & 4 & 7 & 11 & 16 & 22 & 32 & 42 & 58 & 75 & 95 \\
\hline Grading Median & 3 & 11 & 16 & 22 & 29.5 & 41 & 52.5 & 68 & 82.5 & 97.5 \\
\hline
\end{tabular}

Table 3 Basic Performance Indices of Aggregates

\begin{tabular}{|c|c|c|c|c|c|}
\hline Items & $\begin{array}{l}\text { Density } \\
/ \text { g.cm }\end{array}$ & $\begin{array}{l}\text { Crushing } \\
\text { Value } / \% \\
\end{array}$ & $\begin{array}{l}\text { Hydrophilic } \\
\text { Coefficient }\end{array}$ & Flats Content $/ \%$ & $\begin{array}{c}\text { Losangeles wear value } \\
1 \%\end{array}$ \\
\hline Coarse aggregat & 2.7040 & 19.1 & I & 14.2 & 23.7 \\
\hline Mineral Powder & 2.7804 & / & 0.76 & / & / \\
\hline Steel slag Powder & 2.6432 & / & 0.56 & l & l \\
\hline
\end{tabular}

Table 4 Fly Ash Fitness(water sieve method)

\begin{tabular}{|c|c|c|c|c|c|c|c|c|}
\hline \multirow[t]{2}{*}{ Manufacturer } & \multicolumn{2}{|c|}{ Sample Mass /g } & \multicolumn{3}{|c|}{$\begin{array}{c}\text { Knockings substance } \\
\text { Amount } / \mathrm{g}\end{array}$} & \multicolumn{2}{|c|}{$\begin{array}{l}\text { Sample Knockings } \\
\text { Percentage }(0.1 \%)\end{array}$} & \multirow{2}{*}{$\begin{array}{c}\text { Total Knockings } \\
\text { Percentage }(0.1 \%)\end{array}$} \\
\hline & $1 \#$ & $2 \#$ & $1 \#$ & & & $1 \#$ & $2 \#$ & \\
\hline Zhongke & 25.0487 & 25.0534 & 11.9780 & & & $47.8 \%$ & $46.7 \%$ & $47.3 \%$ \\
\hline $\begin{array}{c}\text { Check } \\
\text { Standards }\end{array}$ & \multicolumn{8}{|c|}{ Cement Fineness -- water sieve method GB/T1345-2005 } \\
\hline \multicolumn{9}{|c|}{ Table 5} \\
\hline Type of F & ysh & $\mathrm{Cr}$ & & & $\mathrm{Pb}$ & $\mathrm{Zn}$ & $\mathrm{Cd}$ & $\mathrm{Ni}$ \\
\hline Zhong & & 0.018 & & & 0.03 & 0.309 & 0.00202 & $1.504 \mathrm{E}-05$ \\
\hline
\end{tabular}

The asphalt used in the experiment is made by Sinopec 70 \# matrix asphalt and SBS modifier. The modified agent is formed by thermoplastic elastomer styrene butadiene block copolymer (SBS). The modified agent is linear, $\mathrm{S} / \mathrm{B}$ ratio is 40:60, the molecular weight is not more than 100000 , and it is a cellular granular material with white. Their technical indicators are shown in table $6,7$. 
Table 6 Technical Indicators of 70\# Matrix Asphalt

\begin{tabular}{ccc||ccc}
\hline \multirow{2}{*}{ Items } & & $\begin{array}{l}70 \# \\
\text { Matrix } \\
\text { Asphalt }\end{array}$ & & Items & $\begin{array}{l}70 \# \\
\text { Matrix } \\
\text { Asphalt }\end{array}$ \\
\hline $\begin{array}{c}\text { Penetration } \\
/ 0.1 \mathrm{~mm}\end{array}$ & $15^{\circ} \mathrm{C}$ & 23.0 & Filmy & Penetration $/ 0.1 \mathrm{~mm}$ & $15^{\circ} \mathrm{C}$ \\
& $25^{\circ} \mathrm{C}$ & 71.3 & $\begin{array}{c}\text { Heating } \\
\text { Operational } \\
\text { Test }\end{array}$ & $25^{\circ} \mathrm{C}$ \\
& $30^{\circ} \mathrm{C}$ & 138 & & $30^{\circ} \mathrm{C}$ \\
\hline & $5{ }^{\circ} \mathrm{C}$ & $\begin{array}{c}\text { Not } \\
\text { Dound } \\
\text { Ductility } / \mathrm{Cm}\end{array}$ & $70^{\circ} \mathrm{C}$ Penetration Ratio $/ \%$ & 58.2 \\
& $10^{\circ} \mathrm{C}$ & $\begin{array}{c}\text { Found } \\
58\end{array}$ & $\begin{array}{l}\text { Mass Loss } / \% \\
\text { T800/ } /{ }^{\circ} \mathrm{C}\end{array}$ & 0.71 \\
\hline Soft Point $/{ }^{\circ} \mathrm{C}$ & 47.4 & & $\mathrm{~T} 1.2 /{ }^{\circ} \mathrm{C}$ & 45.0058 \\
\hline
\end{tabular}

Table 7 Technical Indicators of SBS modified agent

\begin{tabular}{clcl}
\hline Items & Indexes & Items & Indexes \\
\hline Microstructure & Linear & Tensile Strength $/ \mathrm{Mpa35min} \geq$ & 21.0 \\
Combinated Styrene Content & 40 & Elongation At Break $/ \% \geq$ & 600 \\
/ $\% \mathrm{Wt}$ & & & \\
Volatile $/ \% \leq$ & 1.5 & Tensile Set At Break $/ \% \leq$ & 50 \\
Total Ash $/ \% \leq$ & 0.1 & Tear Strength $/ \mathrm{Kn} / \mathrm{M}$ & 40.0 \\
Stretching Stress $/ \mathrm{Mpa} \geq$ & 3.0 & SBS Flow Speed $/ \mathrm{G} / 10 \mathrm{~min}$ & $0.3-0.8711$ \\
\hline
\end{tabular}

\subsection{Testing Method}

\subsubsection{Strength Testing Methods}

(1) Cement mortar strength

According to "Method of Testing cement-Determination of strength" (GB/T 17671-1999) to test the strength. Cement sand mix ratio is cement: standard sand: water $=450 \mathrm{~g}: 1350 \mathrm{~g}: 225 \mathrm{~g}$. After mortar mixer mixes, use glue sand plain bumper to shape $40 \mathrm{~mm} \times 40 \mathrm{~mm} \times 160 \mathrm{~mm}$ prism specimens, curing in water and then demoulding; Separately testing their flexural and compressive strength after 3 or 28 days' curing.

(2) Strength test of cement solidified fly ash

According to the " Test Method for water requirement of normal consistency, Setting Time and soundness of the Portland cement " (GB/T 1346-2011) to test the water content of the standard consistency of different fly ash, cement and fly ash ratio, and then according to the "Method of Testing cement-Determination of strength" (GB/T 17671-1999) to shape cube samples(40 mm x 40 $\mathrm{mm} \times 40 \mathrm{~mm}$ ), the curing condition is $20 \pm 3{ }^{\circ} \mathrm{C}$, and the relative humidity is greater than $90 \%$. Test compressive strength of different specimens after 7 days' and 28 days' curing.

(3) Strength test of new consolidation agent solidified fly ash

According to the different ratio of fly ash, slag, sodium fluosilicate and fly ash to choose the amount of water glass, ensure the samples with the paste mixer can be the normal molding.

According to "Method of Testing cement-Determination of strength" (GB/T 17671-1999) to shape the cement mortar cube specimen $(40 \mathrm{mmx} 40 \mathrm{mmx} 40 \mathrm{~mm})$, the curing condition was $20 \pm 3^{\circ} \mathrm{C}$, maintenance of the air relative humidity is greater than $90 \%$. Test compressive strength of different specimens after 7 days' and 28 days' curing.

\subsubsection{Leaching Rate Of Heavy Metals Test}

The digestion of solidified fly ash is though "solid waste-Extraction procedure for leaching toxicity-horizontal vibration method"(HJ557-2010). After 28 days' curing, keep the samples under $105^{\circ} \mathrm{C}$ for 24 hours in the electric thermostatic and isothermal blast drying oven; Get the samples grinded to small pieces which particle size is not more than $5 \mathrm{~mm}$; Take the dry-basis samples $10 \mathrm{~g}$, put 
into $200 \mathrm{ml}$ polyethylene bottles; Add $100 \mathrm{ml}$ of deionized water as leaching agent into the bottle, lid tightly and fixe on the horizontal vibration machine, and then adjust the frequency for $110 \pm 10$ times / min to oscillating leaching under the room temperature for $8 \mathrm{~h}$ and then standing for $16 \mathrm{~h}$; Using filter (or paper) pre-installed well for ordinary filtration and collect all the leaching solution, shaking for analysis. If not timely analysis of the leaching solution, $1 \%$ concentrated nitric acid should be added to the leaching solution, and preservation time should be not more than 1 weeks. Heavy metals content were detected by spectrophotometric determination in the leaching solution.

\subsubsection{Experimental Method Of Asphalt Mixture}

By the previous experiment, the range of asphalt content is about 4.7\%-5.2\%. The optimal dosage of SBS modified asphalt was $4.8 \%$. After determining the optimum asphalt content, the fly ash is used to replace part of the asphalt mixture, and the performance is determined by Marshall test and split test.

(1) Marshall Experimental Method

Marshall shapes the $\Phi 101.6 \mathrm{~mm} \times 63.5 \mathrm{~mm}$ of specimens. The specimens side in a half-circle Marshall die, make specimen under certain confining. Compress test piece to the destruction of the pressure in Newton (N)called Marshall Stability; The amount of compression of specimens destroyed indicates deformation performance, that is called the flow value which unit is $0.1 \mathrm{~mm}$. The temperature of the experiment is $60^{\circ} \mathrm{C}$, which simulates the highest temperature of the asphalt pavement.

Marshall residual stability (MS0)the ratio is both a specimen in $60^{\circ} \mathrm{C}$ water for Marshall stability after $48 \mathrm{~h}(\mathrm{MS} 1)$, and that(MS2)immersed in $60^{\circ} \mathrm{C}$ water for $30 \mathrm{~min}$. It indicates the water stability of asphalt mixture, it indirectly reflects the adhesivity of asphalt and stone. Computation formula is as follows:

$$
M S_{0}=\left(M S_{1} / M S_{2}\right) \times 100 \%
$$

$M S_{0}$ - Residual strength ratio of the specimens after immersed in water, \%;

$M S_{1}$ - Marshall strength after immersed in water for $48 \mathrm{~h}, K N$;

$M S_{2}$ - Marshall strength after immersed in water for $30 \mathrm{~min}, K N$;

(2) Split Experimental Method

Carry out freeze thaw split crack test according to the improvement law of Lotman. Shape the samples which diameter is $\Phi 101.6 \mathrm{~mm} \pm 0.25 \mathrm{~mm}$ with standard Marshall hammer compaction method. The sample is $63.5 \mathrm{~mm} \pm 1.3 \mathrm{~mm}$ height, give each both sides hits for 50 times, and strictly control the height and the deviations, height deviation shall not be greater than $2 \mathrm{~mm}$. The subjects were divided into two groups, each group was not less than 4 pieces. The first group of specimens was kept in the indoor and save the backup, and the second groups were treated by the following method:

a. Immersed in water for $20 \mathrm{~min}$ at room temperature;

b. Immersed in water and vacuum pumping under the vacuum condition of $98.3 \mathrm{kpa}-98.7 \mathrm{kpa}$;

c. Put specimens in plastic bags, add $10 \mathrm{ml}$ water into the bag sealed, and then keep specimens under $-18^{\circ} \mathrm{C}$ in the refrigerator for $16 \mathrm{~h} \pm 1 \mathrm{~h}$;

For the second group test pieces after the above processing, put the first group and the second group of specimens into water under the constant temperature $25 \pm 0.5^{\circ} \mathrm{C}$ over 2 hours. Using the modified split test instrument (adding a layering with width $12.7 \mathrm{~mm}$ in a radial direction, ensure the specimens were split along the radial direction); It can also be carried out in the Marshall test instrument or MTS material testing machine. The splitting strength(RT1,RT2) of the first group and the second group were measured respectively, and then get splitting strength ratio TSR, as shown in (2):

$T S R=\left(R_{T 2} / R_{T 1}\right) \times 100 \%$

$T S R$ - Strength ratio of specimens;

$R T_{1}$ — The splitting strength of freeze thaw specimens;

$R T_{2}$ - The splitting strength of ordinary specimens.

\subsection{Results And Discussion}




\subsubsection{Strength test results}

The strength data of the samples are shown in table 8-11. Comparing table 8-11 can be found that the test strength of samples consisted by fly ash and cement with different ratio generally decreased; From the table 9 , it found the compressive strength of specimens are greatly decreased with fly ash proportion increased, the largest decline reached 75\%; Comparing table 10-11 can be found, when activator is $600 \mathrm{~g}$, the compressive strength of the samples consisted by new consolidation agent and fly ash is much good, but it is still lower than that of in cement mortar strength, the maximum can reach $48.2 \%$ of the compressive strength of cement mortar. The experimental results is quite successful.

Table 9 Strength Of Cement Solidified Fly Ash

\begin{tabular}{|c|c|c|c|c|}
\hline Fly Ash Types & $\begin{array}{c}\text { Cement: Fly } \\
\text { Ash }\end{array}$ & Ages & $\begin{array}{c}\text { Compressive } \\
\text { Strength }(\mathrm{MPa})\end{array}$ & Remarks \\
\hline \multirow{8}{*}{ Zhongke } & \multirow{2}{*}{$1: 1$} & 7 & 20.6 & / \\
\hline & & 28 & 27.6 & / \\
\hline & \multirow{2}{*}{$1: 1.5$} & 7 & 14.0 & / \\
\hline & & 28 & 16.0 & 1 \\
\hline & \multirow{2}{*}{$1: 2$} & 7 & 5.6 & \multirow{4}{*}{$\begin{array}{l}\text { The } \\
\text { specimen is } \\
\text { not regular } \\
\text { and has a } \\
\text { mushroom } \\
\text { shape. }\end{array}$} \\
\hline & & 28 & 9.0 & \\
\hline & \multirow[b]{2}{*}{$1: 2.5$} & 7 & 5.1 & \\
\hline & & 28 & 7.5 & \\
\hline Check Standards & \multicolumn{4}{|c|}{$\begin{array}{l}\text { " Method of Testing cement-Determination of strength" (GB/T } \\
\text { 17671-1999) } \\
\text { "Standard for test method of mechanical properties on ordinary } \\
\text { concrete"(GB/T 500081-2002) }\end{array}$} \\
\hline
\end{tabular}

Table 10 Strength Of New Consolidation Agent Solidified Fly Ash (Activator 600g)

\begin{tabular}{|c|c|c|c|c|c|c|c|c|}
\hline Items & Types & $\begin{array}{l}\text { Fly } \\
\text { Ash } \\
(\mathrm{g}) \\
\end{array}$ & $\begin{array}{l}\text { Consolidatio } \\
\text { n Agent(g) }\end{array}$ & $\begin{array}{c}\text { Accelerato } \\
\text { r } \\
\text { Dosage }(g)\end{array}$ & $\begin{array}{l}\text { Activato } \\
\mathrm{r}(\mathrm{g})\end{array}$ & $\begin{array}{c}\text { Ages } \\
\text { (days } \\
\text { ) } \\
\end{array}$ & $\begin{array}{c}\text { Compressive } \\
\text { Strength } \\
(\mathrm{MPa})\end{array}$ & Remarks \\
\hline \multirow{6}{*}{ Zhongke } & \multirow{2}{*}{$\mathrm{A} 3 \mathrm{~B} 1 \mathrm{C} 3$} & \multirow{2}{*}{357} & \multirow{2}{*}{143} & \multirow{2}{*}{8.6} & \multirow{2}{*}{600} & 7 & 14.8 & 1 \\
\hline & & & & & & 28 & 20.0 & 1 \\
\hline & \multirow{2}{*}{$\mathrm{A} 3 \mathrm{~B} 2 \mathrm{C} 1$} & \multirow{2}{*}{300} & \multirow{2}{*}{200} & \multirow{2}{*}{4.0} & \multirow{2}{*}{600} & 7 & 19.4 & 1 \\
\hline & & & & & & 28 & 21.7 & 1 \\
\hline & \multirow{2}{*}{$\mathrm{A} 3 \mathrm{~B} 3 \mathrm{C} 2$} & \multirow{2}{*}{250} & \multirow{2}{*}{250} & \multirow{2}{*}{10.0} & \multirow{2}{*}{600} & 7 & 20.9 & 1 \\
\hline & & & & & & 28 & 23.3 & 1 \\
\hline
\end{tabular}

Table 11 Strength Of New Consolidation Agent Solidified Fly Ash (Activator 620g)

\begin{tabular}{|c|c|c|c|c|c|c|c|c|}
\hline Items & Type & $\begin{array}{l}\text { Fly } \\
\text { Ash } \\
(\mathrm{g})\end{array}$ & $\begin{array}{c}\text { Consolidatio } \\
\text { n Agent(g) }\end{array}$ & $\begin{array}{c}\text { Accelerato } \\
\mathrm{r} \\
\text { Dosage }(\mathrm{g})\end{array}$ & $\begin{array}{l}\text { Activato } \\
\mathrm{r}(\mathrm{g})\end{array}$ & $\begin{array}{c}\text { Ages } \\
\text { (days } \\
\text { ) } \\
\end{array}$ & $\begin{array}{l}\text { Compressive } \\
\text { Strength } \\
(\mathrm{MPa})\end{array}$ & Remarks \\
\hline \multirow{5}{*}{ Zhongke } & A3B1C3 & 357 & 143 & 8.6 & 620 & $\begin{array}{c}7 \\
28\end{array}$ & $\begin{array}{l}13.0 \\
15.1\end{array}$ & $\begin{array}{l}1 \\
1\end{array}$ \\
\hline & \multirow[b]{2}{*}{$\mathrm{A} 3 \mathrm{~B} 2 \mathrm{C} 1$} & \multirow[b]{2}{*}{300} & \multirow[b]{2}{*}{200} & \multirow[b]{2}{*}{4.0} & \multirow[b]{2}{*}{620} & 7 & 16.7 & \multirow{2}{*}{$\begin{array}{c}\text { Big } \\
\text { unfilled } \\
\text { corner }\end{array}$} \\
\hline & & & & & & 28 & 13.7 & \\
\hline & \multirow[b]{2}{*}{$\mathrm{A} 3 \mathrm{~B} 3 \mathrm{C} 2$} & \multirow[b]{2}{*}{250} & \multirow[b]{2}{*}{250} & \multirow[b]{2}{*}{10.0} & \multirow[b]{2}{*}{620} & 7 & 19.5 & \multirow{2}{*}{$\begin{array}{c}\text { Big } \\
\text { unfilled } \\
\text { corner }\end{array}$} \\
\hline & & & & & & 28 & 13.6 & \\
\hline
\end{tabular}

2.3.2 Leaching ratio of heavy metals for the new consolidation agent of fly ash after 28 days' curing 
The leaching ratio of heavy metals in each group was determined in the experiment. Figure 1 shows the consolidation effect of cement mortar and new consolidation agent for heavy metals. By comparison, it is found that the new consolidation agent consolidation effect is similar with that of cement motar or it is even the same consolidation effect with cement motar for $\mathrm{Cd}$ and $\mathrm{Ni}$. In the figures, it can also be indicated that the effect with different kinds of activator added in new consolidation agent, the influence on consolidation effect is not very obvious, the smallest difference is less than 0.001 . ( consolidation ratio $=1$ - leaching ratio).
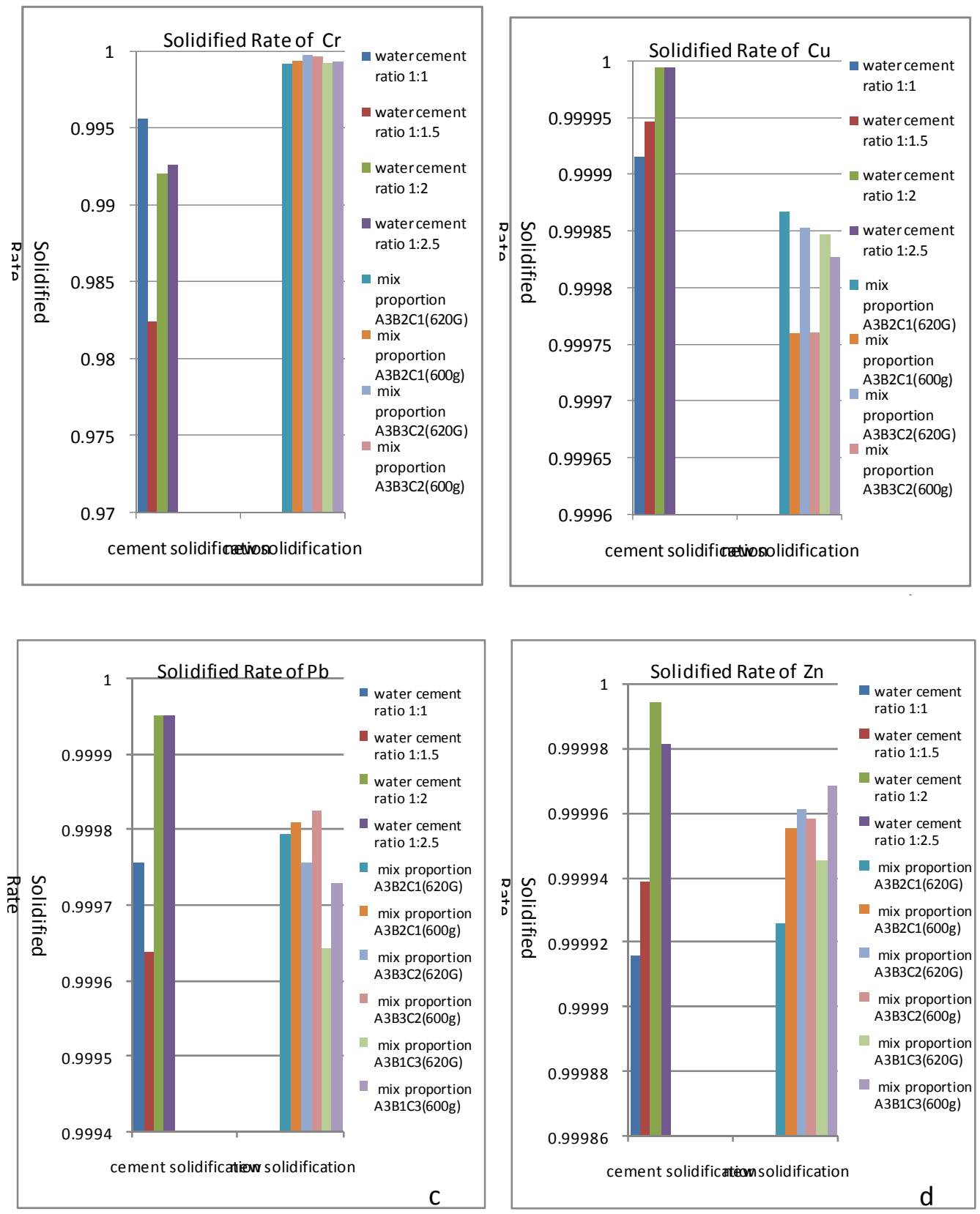

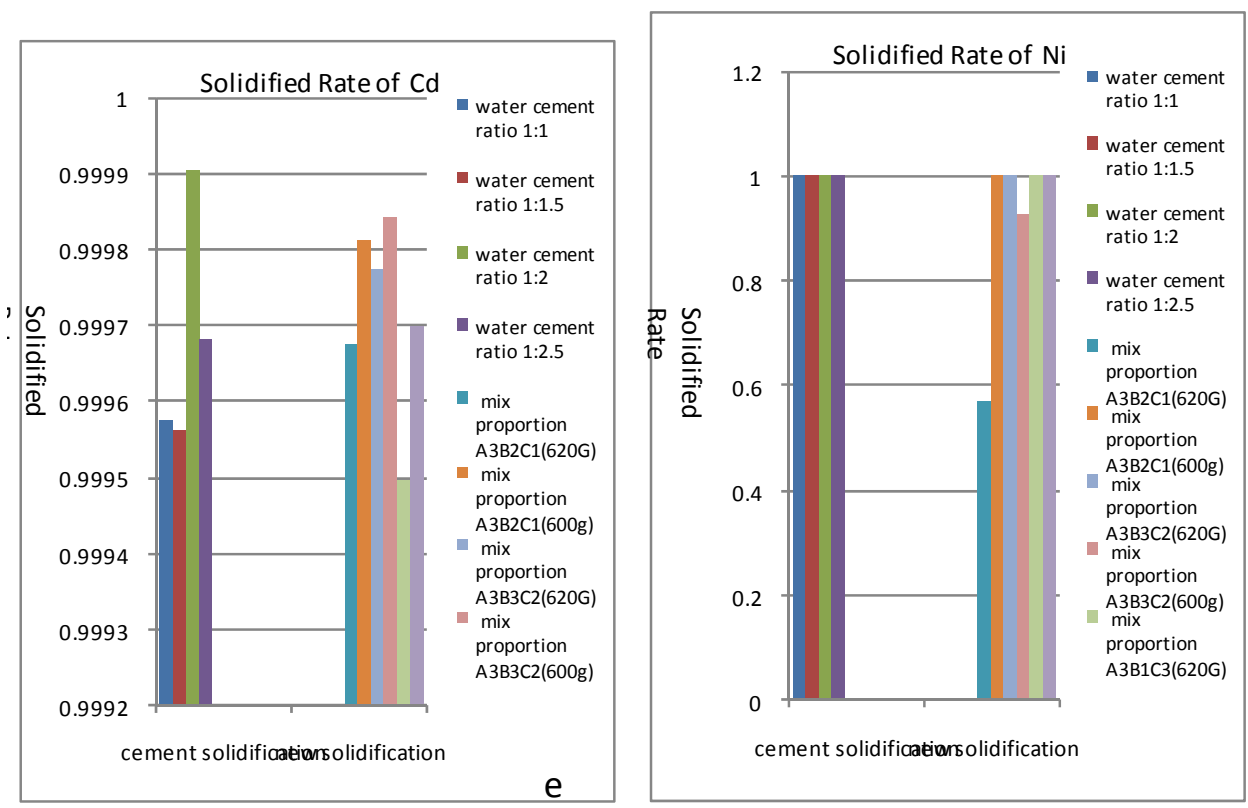

Figure 1 The Consolidation Ratio Of Different Consolidation Agent Curing Fly Ash After 28 Days' Curing

2.3.3Physical and mechanical properties of asphalt mixture with fly ash

(1) Marshall test results of asphalt mixture

Table 12 is the Marshall test results of asphalt mixture with fly ash consolidation partially or completely replace mineral material. As it shown by the experiment results, using waste incineration fly ash to replace totally or partially mineral powder can improve the Marshall stability and residual stability of asphalt mixture. With the increase of the solid content of the fly ash, the Marshall stability and the residual stability of the fly ash are gradually increased. When the content reached $75 \%$, Marshall stability reached the maximum; The content kept increasing, the Marshall stability would decrease slightly, otherwise residual stability would be improved in some way. In this experiment, the optimum mix amount of the solid waste incineration fly ash is $75 \%$.

Table 12 Marshall Test Results Of Asphalt Mixture

\begin{tabular}{ccccccc}
\hline \multirow{2}{*}{ Indexs } & Asphalt & \multicolumn{5}{c}{ Percentage of Fly Ash Induration Substituted for Slag $/ \%$} \\
\cline { 3 - 6 } & Content & 0 & 25 & 50 & 75 & 100 \\
\hline Marshall stability/KN & 4.8 & 11.44 & 11.97 & 12.35 & 13.10 & 12.94 \\
Flow Value/0.1mm & 4.8 & 29.5 & 27.8 & 31.9 & 28.6 & 30.2 \\
Soaking Marshall stability & 4.8 & 9.76 & 10.43 & 11.18 & 11.95 & 11.87 \\
$/ K N$ & 4.8 & 85.3 & 87.1 & 90.5 & 91.2 & 91.7 \\
Residual Stability/\% & & &
\end{tabular}

(2) Water Stability Performance of Asphalt Mixture

Freezing and thawing split test with fresh water, sea water and sulfate solution containing $5 \% \mathrm{Na} 2 \mathrm{SO} 4$ was carried out, the results are shown in table 13. Experimental results show that the addition of MSWI fly ash can significantly improve the water stability of asphalt mixture. The anti-water damage ability of asphalt mixture added fly ash is more prominent in the fresh water, and the TSR value is more than $75 \%$, which reflects the advantages of the MSWI incineration fly ash induration. The reason that the ash of MSWI incineration fly ash can improve the water stability is that the solid waste incineration fly ash is alkaline material; While the asphalt contains carboxylic acid and linoleic acid; When the fly ash evenly distributed to the asphalt mixture, there is a chemical reaction producing a matter with strong adsorption effect. These products sticked in the aggregate surface can't easily be peeled off, and can improve the water stability of asphalt mixture. 
In addition, ,the water stability of asphalt mixture in different media is obviously different from the test results, and the TSR value of asphalt mixture reaches the maximum in fresh water, the second in seawater and the worst in sulfate solution.

Table 13 Water Stability Performance Of Asphalt Mixture

\begin{tabular}{ccccc}
\hline Materials & Curing water & $\begin{array}{c}\text { Cleavage strength } \\
\text { /MPa }\end{array}$ & $\begin{array}{c}\text { Freeze-thaw } \\
\text { Cleavage strength } \\
\text { /MPa }\end{array}$ & TSR/\% \\
\hline Base asphalt & Fresh Water & 1.11 & 0.87 & 78.1 \\
Mixture & Sea Water & 1.01 & 0.75 & 73.8 \\
\hline Asphalt Mixture & Sulfate Solution & 0.87 & 0.60 & 69.4 \\
Mixed Sludge & Fresh Water & 1.31 & 1.06 & 81.2 \\
Consolidation & Sea Water & 1.22 & 0.94 & 77.3 \\
Body & Sulfate Solution & 1.04 & 0.77 & 74.5 \\
\hline
\end{tabular}

\section{Conclusion:}

1.The new curing agent's consolidate effect of heavy metal ion infly ash is much better than cement. However, the mix proportion's selection of this new curing agent should be noticed in order to choose a mix proportion preferentially which has good curing effect.

2. Ni fly ash cured by cement even has adverse effect, which means Ni content measured has not reduced but even increased. The reason may be cement causes compound containing $\mathrm{Ni}$ in the fly ash resolving and producing more soluble Ni ions.

3. The result of road asphalt mixture performance test shows that asphalt makes up of MSWI fly ash consolidation which adapted this consolidation technology, it's physical and mechanical properties are better than original bituminous mixture. And it can be used as padding in the asphalt mixture production.

\section{Acknowledgments}

This work is Ningbo Social Development Research Project, "Solidification Technology Of Municipal Solid Waste Incineration Fly Ash And Its Utilization" supported by Ningbo Science And Technology Projects under grant 2011C50018.

\section{Reference}

[1] Sawell S E, Chancller A J, Eighmy T T, An international perspective on the characterization and management of residues from MSW incinerators. Biomass and Bioenergy, 9(1995) 377- 386.

[2] $\mathrm{H}$ olbert G Lighty J S, Trace metals behavior during the thermal treatment of paper-mill sludge. Write M anagement, 18(1998) 423-431.

[3] ZHANG Yingmin, SHANG Xiaobo, LI Kaiming, Current situation and management strategy of municipal solid waste treatment technology,Ecology and Environmental Sciences,20(2011) 389-396.

Reference to a chapter in an edited book:

[4] Ye Xiuya, Characterization of MSWI Fly Ash and Synergistic Disposal with Landfill Leachate, South China University of Technology,Guangzhou,2012.

[5]Liu Fuyao,Experimental Study On Solidification Of Medical Waste Incinerator Fly Ash By Mixng With Asphal, Southwest Jiaotong University,Chengdu, 2007. 
[6]Peng Wen, The Leaching Behavior of Heavy Metals from MSWI Fly Ash and Experimental Study on Solidification in Treating Fly Ash with Asphalt, Zhejiang University, Hangzhou,2004. 